\title{
Warrior and peacekeeper role identities: associations with self-esteem, organizational commitment and organizational citizenship behavior
}

DOI 10.2478/jms-2019-0002

Received October 8, 2018; accepted April 17, 2019

\begin{abstract}
This article focuses on military role identity by assessing the relations between demographic variables and warrior and peacekeeper role identities and by examining the potential influence of these role identities on self-esteem, organizational commitment and organizational citizenship behavior (OCB) in a crossnational sample. A questionnaire was distributed to military members in four participating countries: Belgium, Estonia, Canada and the Netherlands $(n=831)$. The findings show that demographic variables (i.e., age, gender, marital status and unit) are related to military role identity, and that military role identity predicts self-esteem, organizational commitment and OCB. In particular, multiple regression analyses demonstrate that peacekeeper role identity predicts self-esteem, organizational commitment and OCB, whereas warrior role identity only predicts organizational commitment and OCB, and further, that peacekeeper role identity is a stronger predictor of the outcome variables measured. The theoretical and practical implications, including providing commanders with information to assess their units' mindsets, and mechanisms to improve self-esteem, commitment, OCB, are discussed. Finally, the limitations of this study and its potential for future research are described.
\end{abstract}

*Corresponding author: Tessa op den Buijs, Faculty of Military Sciences, Netherlands Defence Academy, Hogeschoollaan 2, P.O. Box 90002, 4800 PA, Breda, the Netherlands. Tel.: +31 (0) 76-5273780; E-mail: Tp.od.buijs@mindef.nl

Wendy Broesder, Faculty of Military Sciences, Netherlands Defence Academy, Breda, the Netherlands

Irina Goldenberg, Director General Military Personnel Research and Analysis (DGMPRA), Department of National Defence (DND), Canada Delphine Resteigne, Royal Military Academy in Brussels, Belgium Juhan Kivirähk, International Centre for Defence and Security (ICDS), Tallin, Estonia
Keywords: military role identity, self-esteem, organizational commitment, organizational citizenship

\section{Introduction}

After both World Wars and the end of the Cold War, the role of the military shifted significantly toward "Operations Other Than War" (OOTW). It is broadly acknowledged that the role of the military in those operations differs from the traditional "warrior role". Contemporary missions require soldiers to have and draw on multiple role identities, encompassing both the warrior and the peacekeeper roles to achieve success, and missions require "junior leaders to be warriors, peacekeepers and nation builders-simultaneously" (Azari et al. 2010; Wong 2004, p. 4).

Insight into soldiers' role identity is important because role identity predicts behavior and future performance. The need for this knowledge is even more urgent in unpredictable and dangerous situations (Op den Buijs et al. 2012). Military role identity is also an important consideration; in that, it affects soldiers' self-esteem and other important outcomes, such as commitment (Wong 2004), retention (Griffith 2009) and working in cooperation, with other countries' armed forces (Task group HFM-163 2012). For commanders, it is therefore important to know that their soldiers' mindset is in accordance with the situational demands during deployment. Military cooperation with other countries' armed forces in operations further emphasizes the importance of knowledge about different ways of perceiving the military role. Current peace operations bring together diverse actors with different national, institutional and personal backgrounds. Understanding each other's point of view may improve cooperation during deployment (Task group HFM-163 2012).

Since the end of the Cold War, the military role has been qualified as a unidimensional bipolar construct (Franke 1999a, 1999b; Reed and Segal 2010). The more a soldier 
takes on the role of a warrior, the less the soldier takes on the role of a peacekeeper, and vice versa. ${ }^{1}$ Although Johanson et al. (2013) conceptualized military identity as a multidimensional construct, besides idealism, professionalism and individualism, they used "warriorism" as a typical military component, but did not focus on the peacekeeper role. With the construction of the Warrior Peacekeeper Role Identity Questionnaire (WPRIS), it was demonstrated that the concept of military role identity is a bidimensional construct: Dutch soldiers identify with both roles simultaneously, and a preference for one role is not related with a preference for the other role (Broesder 2011; Broesder et al. 2015; Op den Buijs and Broesder 2013).

In the broader perspective of current military operations, research shows that when military role identity is combined with the performance of tasks during deployment, it is, for example, related to gender, age, organizational commitment, organizational citizenship behavior (OCB) and role strain (Broesder 2011; Broesder and Op den Buijs 2015). For example, soldiers with different backgrounds (gender and age) identify, to the same extent, with the peacekeeper role, while the extent to which soldiers identify with the warrior role varies with the nature of dominant tasks (being part of a combat unit or a combat-support unit). Additionally, there is a difference in the occurrence of role strain in relation to the performance of tasks during deployment for "warriors" and "peacekeepers." In fact, only combat soldiers suffer from role strain or psychological ambiguities when tasks during deployment are less warrior-like than they expected (Bartone and Vaitkus 1998; Britt 1998; Broesder 2011; Franke 1999b; Op den Buijs and Broesder 2013). These studies make important contributions to our knowledge about military role identity by showing that soldiers ${ }^{2}$ nowadays do not perceive the warrior role as the sole military role and by demonstrating important relationships between military role identity and demographic variables and work-related variables (Broesder and Op den Buijs 2015).

However, there are still many gaps in our understanding of military role identity and its associations with the behavior and outcomes of military members, particularly as related to deployment, including examination of how military role identity may affect self-esteem, organizational commitment and OCB. In addition, recently, military role identity studies focus on military transition theory, and

1 For example, the instruments developed and used by Franke and Reed and Segal were meant to assess attitudes toward the peacekeeper role or the warrior role, and the focus on these studies was to measure the military role as a unidimensional bipolar construct. 2 In this article, a soldier can be a male or a female, and "he" can also be read as "she." thus concern veterans instead of actively serving soldiers. Furthermore, most of these identity studies are related to (mental) health or well-being instead of identity-associated behavior or performance during deployment (Brewin et al. 2011; Griffith 2010; Haslam et al. 2009; Lancaster and Hart 2015; Smith and True 2014). Moreover, although it is contended by numerous scholars that soldiers' military role identity will influence their actions and their work in international missions and operations (international cooperation) (Griffith 2011; Hogg et al. 1995; Thoits 1991; Wiley 1991), the role of military identity in relation with performance has not frequently been examined.

The main goal of this study is to examine the influence of select demographic variables in the formation of military role identity and to assess the degree to which military role identity is associated with soldiers' selfesteem, organizational commitment and OCB. The theory and the proposed conceptual model are described in the following sections.

\subsection{Military role identity}

Role identities are self-definitions that people apply to themselves as a result of the structural role positions they occupy (Hogg et al. 1995; Turner and Tajfel 1986). Identity theory sets out individuals' role-related behavior. Meanings of a role and expectations related to the role are, in part, culturally derived as individuals are socialized into their roles (Goffman 1975), but an individual's own understanding of what a role means also becomes part of one's role identity. Role identity is a type of self-identity. Self-identity is conceptualized as a definition of self as a person who performs a particular role or behavior and defines a unique sense of the self and the relationship with the outside world. Role identity is not a static concept but varies in strength as a result of new experiences (Bartel 2001). Importantly, research has shown that role identity predicts behavior patterns and intentions (White et al. 2008).

The extent to which soldiers identify with the military role identity will guide their behavior and their ability to act responsibly (Dalenberg 2017; Thoits 1991), which will influence their performance, including their work in international missions and operations. Our earlier studies on the conceptualization of military role identities demonstrated that soldiers who identified mainly with the warrior role will not only perceive a situation differently from soldiers who identified mainly with the peacekeeper role but will also act differently, and furthermore will be prone to experience more stress (Broesder et al. 2015; Op den Buijs and Broesder 2013). 
On the basis of the earlier research, we expect demographic variables to predict a soldier's role identity. Empirical findings showed that both United States and Dutch male soldiers tend to identify themselves more with the warrior role than female soldiers do (Broesder 2011; Broesder and Op den Buijs 2015; Broesder et al. 2015; Franke 1999b, p. 115; Franke 2000; Franke and Guttieri 2009; Op den Buijs and Broesder 2013). Furthermore, several studies showed that combat soldiers are more warrior-oriented than combat-support ones (Avant and Lebovic 2000; Broesder 2011; Broesder and Op den Buijs 2015; Broesder et al. 2015; Franke and Guttieri 2009; Homan 2007; Op den Buijs and Broesder 2013). A relationship was demonstrated between rank and a commandposition and military role identity; in that, officers have a less salient or persistent identity than private officials and could more easily switch between different military role identities (Broesder 2011; Franke 2000). This is probably a result of the relation between rank, a command-position and level of education. Or as Franke (1999b, p. 111) stated: "Higher levels of education are commonly associated with an enhanced ability to consider and discriminate between an increasing number of alternative choices and with a tendency to base decisions on rational judgments instead of emotional attachments," suggesting that highly educated soldiers are more flexible in switching between identities.

A recent study concerning military role identity of Dutch soldiers in a peacetime location (Broesder and Op den Buijs 2015) shows support for the assumption that role identity varies in strength as a result of new experiences; relationships were demonstrated between warrior identity and number of deployments, and the year of the soldiers' latest mission. For example, soldiers were less warrior-oriented during less extreme missions undertaken before 2005 than during missions in 2010 in which the level of violence was much higher (e.g., Afghanistan issue).

\subsection{Self-esteem, organizational commitment and organizational citizenship behavior}

Self-esteem, organizational commitment and OCB have been shown to be related to identity of the warrior and peacekeeper (Broesder and Op den Buijs 2015).

Self-esteem is defined as a global evaluation of the self and involves feelings of self-acceptance, self-liking, self-respect, self-competence, self-knowledge and selfworth (Wahyu Ariani 2012). It is typically measured by the degree to which the person endorses various evaluative statements about the self (Judge et al. 1998). Rosenberg (1965) described self-esteem as a favorable or unfavorable attitude toward the self. Self-esteem may also be conceptualized as the self-perceived value that individuals have of themselves within a specific organizational context. It reflects people's sense of their own value within a particular setting and reflects the extent to which their need for self-esteem is met by performing their role in the organization (Wahyu Ariani 2012) and is required for productive behavior in general (Baumeister et al. 2003).

However, there is much discussion and indeed difficulty in conceptualization and measuring of self-esteem, and the extent to which self-esteem predicts work-related behavior is not clear. For example, an overview study showed that the modest correlations between self-esteem and performance do not indicate that high self-esteem leads to good performance (Baumeister et al. 2003). Instead, job performance in adults is sometimes related to self-esteem, although the correlations vary widely, and the direction of causality has not been established. Occupational success may boost self-esteem rather than the reverse (Baumeister et al. 2003).

Some studies support the buffer hypothesis, which means high self-esteem mitigates the effects of stress. Positive self-esteem is considered an important quality of employees to cope effectively with adversity in any demanding work situation (Lazarus and Folkman 1984), and Schacter et al. (2009) discovered, many years later, that self-esteem is related to more appropriate strategies to cope with stress and psychological well-being. Petlichkoff (2004) referred to mental skills (e.g., self-confidence, goal-setting skill, ability to concentrate and ability to control emotions) as being important contributors to psychological well-being and self-esteem in particular.

Furthermore, self-esteem fulfils an important role in a person's status and acceptance in social groups and is related to strong feelings of competence and low beliefs in taking risks. People with self-esteem want to realize their goals and have a more stable emotional and mental stance toward life in general (Errol and Orth 2011; Rosenberg 1965). Britt (2003) stated that peacekeepers will undoubtedly attempt to make sense of the situation if they are required to act in ways that might be inconsistent with their identity. The extent to which peacekeepers derive meaning from their experience will determine how they adapt to the peacekeeping mission. If a military operation has a meaning that makes sense, then their performance will be high. Thus, the individual's perception of the operation is relevant to the soldier's identity and contributes to a high level of self-esteem. This is important for soldiers in handling stressful situations and persisting in task performance (Van Boxmeer et al. 2008). In general, self-esteem is important for military personnel, and therefore, we 
expect a relationship between military role identity and self-esteem.

Organizational commitment is a key construct in organizational research, including military organizational research (Gade 2003). The three-component model of commitment (Meyer and Allen 1991; Meyer et al. 1993) is the most common model found in organizational commitment research (Jaros 2007; Meyer et al. 2002). This model proposes that organizational commitment is comprised three dimensions. Affective commitment reflects perceptions of attachment and emotional ties to one's organization; normative commitment reflects perceptions of obligation to one's organization; continuance commitment reflects commitment that stems from the perceived costs (economic and social) of leaving the organization (Allen and Meyer 1990; Meyer et al. 1993). Conceptual links between organizational social identity and organizational commitment, especially affective organizational commitment, are clear; indeed, Meyer et al. (1993) posit that commitment is a psychological state that characterizes the employee's relationship with the organization, and particularly in the case of affective commitment, which implies emotional ties to the organization.

A vast body of research shows the importance of affective organizational commitment to workplace effectiveness, including superior performance (Jaros et al. 1993; Luchak and Gellatly 2007), increased work effort (Fu et al. 2009; Mathieu and Zajac 1990), increased OCB (Meyer et al. 1993), increased retention (Bentein et al. 2005; Griffeth et al. 2000; Meyer et al. 1993; Wiley 1991) and well-being (Meyer et al. 2013).

This vast body of research extends to the military context, showing that soldiers who are committed to the organization are more motivated and more satisfied (Allen 2003; Langkamer and Ervin 2008; Meyer et al. 2013; Van Boxmeer et al. 2008). Thus, understanding the antecedents of organizational commitment, and the processes by which commitment is developed and maintained, is important and is a focus of our study. This importance also includes the degree to which military identity plays a role in the development and maintenance of organizational commitment. Because creating military role identity, and incorporating organizational goals into one's identity, is such an important part of military socialization, we assume a relationship between military role identity and organizational commitment. Recent research findings support this positive relationship between military role identity and organizational commitment (Britt 2003; Broesder 2011; Broesder and Op den Buijs 2015).

Organizational commitment has been shown to predict OCB in turn. OCB is a unique aspect and can be defined as behaviors or activities in a workplace that involve going above and beyond the call of duty. These behaviors are independent and are not explicit and formalized in work procedures and are not directly reflected in formal systems and organizational reward. In order for an organization to function optimally, it is important that employees themselves undertake activities and develop initiatives. For example, employees can help the organization as a whole by following codes of conduct or assisting their colleagues directly, or help others spontaneously with problems in their work. It is recognized that these spontaneous behaviors are important for the effectiveness of the organization and individual performance (Motowidlo et al. 1997) and, as such, with a specific importance for the military and the "good soldier" prototype (Organ 1988, 1994). Furthermore, employees with higher OCB are more satisfied with their jobs, more flexible in their work and more cooperative (Organ et al. 2006).

Although there is no clear consensus in the literature about the dimensions of OCB and its measurement (Gurbuz 2009), there are many aspects which can be considered as OCB within an organization. The most commonly used are Organ's five-dimensional conceptualization such as altruism, conscientiousness, sportsmanship, courtesy and civic virtue (Organ 1988) or Williams and Anderson's two-dimensional conceptualization such as OCB-I behavior directed toward the individual and OCB-O behavior directed toward the organization as a whole (Williams and Anderson 1991).

Despite different conceptualizations, OCB can be seen as a relevant outcome in the military context because it leads to desirable behavior (Dalenberg 2017; Van Boxmeer et al. 2010; Van Creij 2017). With OCB, military personnel feel more responsible and more flexible and are more satisfied with their job (Van Creij 2017).

A stronger military role identity results in more OCB, and because it has an element of helpfulness or altruism and a positive relationship between peacekeeper role identity and OCB has already been shown in Dutch research (Broesder and Op den Buijs 2015), we suggest that a stronger peacekeeper role identity leads to more OCB and stronger helping and supporting attitudes.

\subsection{Relationships}

On the basis of the theory and research outlined earlier, this article examines the relationships between selected demographic variables, military role identity and workrelated variables. First, the influence of certain demographic variables on the military role identities was 
studied. Then, we explored the degree to which military role identity is associated with soldiers' self-esteem, organizational commitment and OCB in regression analysis. The focus of this analysis was on the understanding of the antecedents of self-esteem, organizational commitment and OCB, and the processes by which these outcomes are developed and maintained, including the degree to which military role identity plays a role in the development and maintenance of outcome variables.

\section{Method}

\subsection{Procedure and participants}

Four groups of soldiers (Belgian, Estonian, Canadian and Dutch) completed a paper-and-pencil questionnaire in 2012 and 2013. Participants were asked to fill out the questionnaire anonymously in their home country while they were not on missions. ${ }^{3}$ The questionnaires were collected by the national contact persons and sent to the Netherlands. The four data sets were subsequently merged into one international data set. In total, 831 participants from across the four participating countries completed the questionnaire. The proportions from the four countries were as follows: Belgium (18\%), Estonia (30\%), Canada $(14 \%)$ and the Netherlands (38\%). This sample as a whole was predominately male ( $95.8 \%$ male and $4.2 \%$ female). The average age of participants was 31.7 years $(\mathrm{SD}=8.17)$. The majority of the participants was married or living with a partner (66.4\%). Most participants were army soldiers (98.6\%). The rank categories consisted of privates (41.4\%), NCOs (44.8\%) and officers (13.8\%). ${ }^{4}$ Nearly $40 \%$ of the participants had been deployed once, and $22.6 \%$ had been deployed four or more times. The majority listed Afghanistan (87.1\%) as the location of their last deployment. One-fifth of the participants were unit leaders during the mission, while the majority of the participants

3 Convenience sampling was used to collect the data (Bryman 2016). The contact persons were asked to distribute the questionnaires to as many units as possible. The questionnaires were sent to various units (such as infantry battalions, supply and transport battalions and fire service command). In general, we were asked to collect about 160 questionnaires from the personnel per country, of which 100 from soldiers, 40 from non-commissioned officers and 20 from officers.

4 Although the four countries were very similar concerning the demographics, there was no consensus on the variable rank. There was a difference (bias) in the evaluation of the non-commissioned and private ranks during the mission. Therefore, it was decided to leave this variable out of any further analysis.
Tab. 1: Demographic variables

\begin{tabular}{|c|c|c|c|}
\hline Variables & & $\%$ & $n$ \\
\hline \multirow[t]{2}{*}{ Gender } & Male & 95.8 & 829 \\
\hline & Female & 4.2 & \\
\hline \multirow[t]{3}{*}{ Rank } & Private & 41.4 & 829 \\
\hline & Non-commissioned officers & 44.8 & \\
\hline & Officer & 13.8 & \\
\hline \multirow[t]{5}{*}{ Service } & Army & 98.6 & 830 \\
\hline & Navy & 0.2 & \\
\hline & Air Force & 0.7 & \\
\hline & Military Police & 0.5 & \\
\hline & Other & 0.1 & \\
\hline \multirow[t]{5}{*}{ Marital status } & Married & 34.6 & 829 \\
\hline & With partner & 31.8 & \\
\hline & Alone & 21.8 & \\
\hline & With parents & 9.9 & \\
\hline & Other & 1.8 & \\
\hline \multirow{4}{*}{$\begin{array}{l}\text { Number of } \\
\text { deployments }\end{array}$} & 1 time & 38.1 & 831 \\
\hline & 2 times & 23.2 & \\
\hline & 3 times & 15.9 & \\
\hline & 4 times or more & 22.6 & \\
\hline \multirow{4}{*}{$\begin{array}{l}\text { Country last } \\
\text { deployment }\end{array}$} & Afghanistan & 87.1 & 827 \\
\hline & Lebanon & 1.9 & \\
\hline & Kosovo & 3.3 & \\
\hline & Other ${ }^{\mathrm{a}}$ & 7.6 & \\
\hline \multirow[t]{3}{*}{ Unit } & Combat unit & 60.6 & 822 \\
\hline & Combat-support & 27.7 & \\
\hline & Other ${ }^{\mathrm{b}}$ & 11.7 & \\
\hline \multirow[t]{3}{*}{ Function } & Unit leader & 19.9 & 825 \\
\hline & Unit member & 73.8 & \\
\hline & Individual mission & 6.3 & \\
\hline
\end{tabular}

a"Other" refers to deployments mentioned only once or twice, for example deployments to Congo, Serbia, Sri Lanka and Somalia. b3 = Other: consisted of headquarter/staff, 4 = Other Canada: consisted of advisor/trainer/mentor.

were unit members $(73.8 \%)$. Table 1 presents the demographic variables.

\subsection{The measures}

The questionnaire consisted of three main sections: questions measuring demographic variables, the WPRIS and three scales measuring the outcome variables. The original Dutch questionnaire was translated into English, French and Estonian. The Dutch version was administered in Belgium and in the Netherlands, the English and French in Canada and the Estonian in Estonia. The demographic variables were divided into two categories; general demographic variables (gender, age and marital 
status) and mission-related demographic variables (rank, service, type of unit during the last deployment, number of deployments, country of last deployment and function in last deployment). The variable unit distinguishes "combat unit," "combat-support unit" and "other unit." Function was added to distinguish soldiers' positions during last deployment. Participants were able to choose between being a "unit leader," "unit member" or "individual mission."

The Warrior Peacekeeper Role Identity Scale (WPRIS) was constructed in 2011 (Broesder 2011) and further developed and tested for psychometric quality in 2015 (Broesder et al. 2015). The scale consists of two subscales: Warrior role identity and Peacekeeper role identity. Warrior role identity is measured with seven items representing the conviction that combat is the main military task, including aspects such as fighting and destroying the enemy. Examples include I consider participation in combat operations to be the most important military task and I consider it our military task to use force against anyone who disturbs the peace process. Peacekeeper role identity is measured with six items reflecting the conviction that reconstruction should be the first priority during deployment, that working together and humanitarian relief are important, and that one should always help and work with all people present in the mission area. Examples of items include $I$ consider reconstruction to be a soldier's main task during $a$ mission and I will be deployed on a mission in order to aid the population.

Both identity scales were measured on a five-point Likert scale (from $1=$ strongly disagree to $5=$ strongly agree). The internal consistency of the two subscales of the WPRIS is satisfactory in this study (Cronbach's alpha $=0.72$ and 0.77 , respectively; evidence for the validity of this scale is reported by Broesder et al. 2015).

Self-esteem was measured with the self-esteem scale (SES; Rosenberg 1965) consisting of ten items that measure global self-worth by measuring both positive and negative feelings about the self. In this study, some items were adapted to task performance. For example, I am able to do things as well as most other people was changed into I am able to do things as well as most other colleagues and I wish I could have more respect for myself was changed to I wish I could have more respect for myself at my work. Items were measured on a four-point Likert scale (from $0=$ strongly disagree to 3 = strongly agree; Rosenberg 1965). The internal consistency is satisfactory (Cronbach's alpha $=0.78$ ).

Organizational commitment was measured with five items referring to the extent to which an individual is committed to the organization. These five items were derived from the Dutch Morale questionnaire (Van Boxmeer
Tab. 2: Means, standard deviations and internal consistencies of the scales (Cronbach's alpha; $n=831$ )

\begin{tabular}{lllll}
\hline Scales & & & & \\
\hline & M & SD & Alpha & Likert scale \\
\hline Warrior & 3.35 & 0.64 & 0.72 & $1-5$ \\
Peacekeeper & 3.59 & 0.58 & 0.77 & $1-5$ \\
Self-esteem & 2.23 & 0.43 & 0.78 & $0-3$ \\
Organizational & 4.03 & 0.59 & 0.79 & $1-5$ \\
commitment & & & & \\
OCB & 4.05 & 0.55 & 0.70 & $1-5$ \\
\hline
\end{tabular}

et al. 2010) in which they had been adapted to the military organization. The items were developed to measure the affective commitment, defined as emotional connection or ties to an organization. This is considered to be the most relevant component to measure in relation with military role identity because of the presumed linkage with belonging to an organization. Examples of items are I support the objectives of the armed forces, and I think that the armed forces do a good job. Participants responded to the items using a five-point Likert scale (from $1=$ totally disagree to 5 = totally agree). Reliability is reasonable (Cronbach's alpha $=0.79$ ).

$O C B$ refers to employees who are motivated to work, keep on working and perform additional tasks (Organ 1988). This behavior reflects the willingness of individuals to go above and beyond the prescribed role requirements and exceeds an employee's job description (Katz and Kahn 1966; Organ 1988). Given the focus on behavior and performances related to military identity, we believe that measuring behaviors directed at the individual is therefore most relevant. The three items in this study reflect the altruism dimension of the OCB construct from Organ (1988) and were derived from the Dutch Morale Survey (Van Boxmeer et al. 2010). Items are as follows: If someone has problems with performing his tasks, I will help him; I will intervene of my own accord if that will prevent others from making mistakes and I will intervene of my own accord if that will save someone else a problem. Participants responded to the items using a five-point Likert scale (from $1=$ totally dis $a$ gree to $5=$ totally agree). The scale reliability is reasonable (Cronbach's alpha $=0.70$; evidence for the validity of this scale is reported by Van Boxmeer et al. 2010). Table 2 presents the means, standard deviations and internal consistencies of the measures used. ${ }^{5}$

5 The measures consisted of existing scales and were all validated and reliable scales. The psychometric qualities of these scales have been demonstrated in many studies and repeatedly reproduced. 
Tab 3: Correlations

\begin{tabular}{|c|c|c|c|c|c|c|c|c|}
\hline Variables & 1 & 2 & 3 & 4 & 5 & 6 & 7 & 8 \\
\hline 1. Age & 1 & & & & & & & \\
\hline 2. Gender (male) & -0.01 & 1 & & & & & & \\
\hline 3. Marital (married) & $0.38^{\star \star}$ & 0.06 & 1 & & & & & \\
\hline 4. Unit (combat) & $-0.26^{\star \star}$ & $0.13^{\star \star}$ & $0.09 * \star$ & 1 & & & & \\
\hline 5. Warrior & $-0.18^{\star \star}$ & 0.05 & $-0.09^{\star}$ & $0.26 * \star$ & 1 & & & \\
\hline 6. Peacekeeper & $0.10 * \star$ & $-0.11^{\star \star}$ & -0.01 & -0.02 & $-0.07^{\circ}$ & & & \\
\hline 7. Self-esteem & $0.26^{\star \star}$ & $-0.09^{\star}$ & $0.16^{\star \star}$ & $-0.09 *$ & -0.01 & $0.19^{\star \star}$ & 1 & \\
\hline 8. Organ. comm. & $0.23^{\star \star}$ & $-0.09^{\star \star}$ & 0.06 & 0.01 & $0.14^{\star \star}$ & $0.27^{\star \star}$ & $0.41^{\star *}$ & 1 \\
\hline 9. OCB & $0.18^{\star \star}$ & $-0.10^{\star \star}$ & $0.11^{\star \star}$ & $-0.08^{\star}$ & $0.09^{\star}$ & $0.30^{\star \star \star}$ & $0.41 * \star$ & $0.47^{* *}$ \\
\hline
\end{tabular}

Note: ${ }^{\star \star} p<0.01,{ }^{\star} p<0.05,{ }^{\circ} p=0.05$.

\subsection{The analyses}

Data were analyzed using Statistical Package for the Social Sciences (SPSS 22.0). For the nominal variables, so-called dummy variables were made to prepare them for the correlation and regression analyses. ${ }^{6}$ With multiple regression analyses, we tested the predictor variables of military role identity and afterward we tested the role of military role identity in the relationship with self-esteem, organizational commitment and OCB. ${ }^{7}$ Therefore, we conducted multiple regression analyses to test to what extent military role identities predict self-esteem, organizational commitment and OCB.

\section{Results}

Table 3 presents the correlations for all variables. ${ }^{8}$ With respect to the relations between the demographic (dummy)

\footnotetext{
6 Dummy variables were created by recoding the nominal demographic variables and ordinal background variables into new variables. Gender was recoded into gender (male) with $1=$ male and 0 = female; marital status was recoded into a dummy variable marital status (married) with only two categories: 1 = married or living with partner, $0=$ living alone or with parents. Furthermore, we recoded unit into a dummy variable unit (combat) with two categories: $1=$ combat unit, $0=$ combat support unit or other.

7 Our analyses also explored the role of the military role identities for possible mediation effects, but the correlations were not high enough to conduct relevant and useful mediation. The mediation effects measured with Sobel tests were not significant or very weak (Sobel 1986).

8 The demographic variables function, and number of missions were already left out of the correlation analysis because of statistical reasons. Number of missions were not related to any outcome variable, and the variable function did not have any significant relation with military role identity.
}

variables $^{9}$ and military role identities, age, marital status and type of unit were significantly related to warrior role identity ( $r=-0.18, r=-0.09$ and $r=0.26$, respectively). These findings suggest that when soldiers age, their identification with the warrior role decreases. Those who were living alone without a partner had slightly higher warrior role identity than those married or living with a partner. Not surprisingly, soldiers of a combat unit had greater warrior role identity than those of combat-support units. Gender was not related to warrior role identity, but was negatively correlated with peacekeeper role identity ( $r=-0.11, p<0.01$ ), suggesting that women tend to relate more to the peacekeeper role identity. Furthermore, opposite to the pattern for warrior role identity, age was significantly and positively associated with peacekeeper role identity ( $r=0.10, p<0.01)$, suggesting that as soldiers age, they relate more to the peacekeeper role identity. Marital status and unit showed no association with peacekeeper role identity. ${ }^{10}$

With respect to the relationship between military role identity and the outcome variables, the results demonstrated that peacekeeper role identity was moderately related to all of the outcome variables (self-esteem: $r=0.19$, organizational commitment: $r=0.27$, OCB: $r=0.30$, $p<0.01$ ), but warrior role identity was only related to organizational commitment and OCB and was not significantly

9 See footnote 8 for the dummy variables.

10 In our analyses, we also conducted multiple regression analyses with the demographics as independent variables and the military role identities as dependent variables. The demographic variables explained $8 \%$ of variance in warrior role identity (adjusted $R^{2}=0.08$, $F(4,798)=17.45, p=0.00)$. With unit and age predicting warrior role identity $(\beta=0.22, t=6.20, p=0.00 ; \beta=-0.11, t=-3.05, p=0.00$, respectively). Only $2 \%$ of variance in peacekeeper role identity (adjusted $\left.R^{2}=0.02, F(4,803)=5.02, p=0.00\right)$ was explained by age and gender $(\beta=0.13, t=3.35, p=0.00$; gender: $\beta=-0.10, t=-2.91$, $p=0.00$, respectively). 
related to self-esteem. The relations of warrior role identity with the outcome variables were much weaker than the relations for peacekeeper role identity $(r=0.14$, $p<0.01 ; r=0.09, p<0.05$, respectively). Moreover, the two military role identities were uncorrelated $(r=-0.07$; $p=0.05$ ), supporting the bidimensional construct of military role identity.

\subsection{The relative effects of warrior and peace- keeper role identity on the prediction of self-esteem, organizational commitment and $O C B$}

Multiple regression analyses were conducted to assess the combined and independent effects of the two types of military role identity, after controlling for the effects of the demographic variables entered on the first step. On the second step, the military role identities were entered in the regression analysis to test their combined and independent influence on self-esteem, organizational commitment and OCB.

Table 4 shows that $8 \%$ of variance in self-esteem was explained by the demographic variables age, marital status and gender (age: $\beta=0.22, t=6.13$, $p=0.00$; marital status: $\beta=0.11, t=2.96 p=0.00$; gender: $\beta=-0.09, t=-2.53 p=0.01$ ). After adding military role identity, the explained variance increased with another $3 \%(F(2,803)=12.58, p=0.00)$, and this was explained exclusively by peacekeeper role identity ( $\beta=0.16, t=4.83, p=0.00$ ), which is not surprising given that warrior role identity was not related to self-esteem in the first place.

Table 5 shows that $6 \%$ of variance in organizational commitment was explained by demographic variables (adjusted $\left.R^{2}=0.15, F(4,805)=14.03, p=0.00\right)$. The results demonstrate that age, unit and gender predict this variance, although age predicts a greater variance. Furthermore, the results show that after adding the military role identities, both peacekeeper role identity and warrior role identity predict unique and significant variance in organizational commitment over and above each other $(F(2,803)=43.85, p=0.00)$, although peacekeeper role identity predicts a greater amount of variance $(\beta=0.25, t=7.58, p=0.00 ; \beta=0.20, t=5.93$, $p=0.00$, for peacekeeper and warrior military role identity, respectively).

Table 6 shows the results for OCB. Four percent of the variance in OCB was explained by demographic variables only (adjusted $R^{2}=0.04, F(4,805)=9.48, p=0.00$ ).
Tab. 4: Combined and unique prediction of self-esteem based on military role identity

\begin{tabular}{lllll}
\hline Model summary & \multicolumn{2}{l}{ Self-esteem } & & \\
\hline & $\boldsymbol{R}^{2}$ adjusted & $\boldsymbol{\Delta} \boldsymbol{R}^{\mathbf{2}}$ & $\boldsymbol{F}\left(\boldsymbol{\Delta} \boldsymbol{R}^{2}\right)$ & $\boldsymbol{p}$ \\
\hline Step 1 & 0.08 & 0.08 & 18.22 & 0.00 \\
Step 2 & 0.10 & 0.03 & 12.58 & 0.00 \\
Step 1 & $\boldsymbol{B}$ & $\boldsymbol{\beta}$ & $\boldsymbol{t}$ & $\boldsymbol{p}$ \\
Constant & 1.89 & - & 20.78 & 0.00 \\
Age & 0.01 & 0.22 & 6.13 & 0.00 \\
Marital & 0.10 & 0.11 & 2.96 & 0.00 \\
Unit & -0.01 & -0.01 & -0.18 & 0.86 \\
Gender & -0.19 & -0.09 & -2.53 & 0.01 \\
Step 2 & $\boldsymbol{B}$ & $\boldsymbol{\beta}$ & $\boldsymbol{t}$ & $\boldsymbol{p}$ \\
Constant & 1.40 & - & 8.94 & 0.00 \\
Age & 0.01 & 0.21 & 5.83 & 0.00 \\
Marital & 0.10 & 0.11 & 3.20 & 0.00 \\
Unit & -0.02 & -0.02 & -0.60 & 0.55 \\
Gender & -0.15 & -0.07 & -2.05 & 0.04 \\
Peacekeeper & 0.12 & 0.16 & 4.83 & 0.00 \\
Warrior & 0.04 & 0.06 & 1.60 & 0.11 \\
\hline
\end{tabular}

Tab. 5: Combined and unique prediction of organizational commitment based on military role identity

\begin{tabular}{lllll}
\hline Model summary & \multicolumn{4}{l}{ Organizational commitment } \\
\hline & $\boldsymbol{R}^{2 \text { adjusted }}$ & $\boldsymbol{\Delta}^{\mathbf{2}}$ & $\boldsymbol{F}\left(\boldsymbol{\Delta} \boldsymbol{R}^{2}\right)$ & $\boldsymbol{p}$ \\
\hline Step 1 & 0.06 & 0.07 & 14.03 & 0.00 \\
Step 2 & 0.15 & 0.09 & 43.85 & 0.00 \\
Step 1 & $\boldsymbol{B}$ & $\boldsymbol{\beta}$ & $\boldsymbol{t}$ & $\boldsymbol{p}$ \\
Constant & 3.67 & - & 27.98 & 0.00 \\
Age & 0.02 & 0.25 & 6.84 & 0.00 \\
Marital & -0.01 & -0.01 & -0.15 & 0.88 \\
Unit & 0.11 & 0.09 & 2.48 & 0.01 \\
Gender & -0.29 & -0.10 & -2.78 & 0.00 \\
Step 2 & $\boldsymbol{B}$ & $\boldsymbol{\beta}$ & $\boldsymbol{t}$ & $\boldsymbol{p}$ \\
Constant & 2.10 & - & 10.01 & 0.00 \\
Age & 0.02 & 0.25 & 7.00 & 0.00 \\
Marital & 0.01 & 0.01 & 0.27 & 0.79 \\
Unit & 0.05 & 0.04 & 1.15 & 0.25 \\
Gender & -0.22 & -0.08 & -2.30 & 0.02 \\
Peacekeeper & 0.26 & 0.25 & 7.58 & 0.00 \\
Warrior & 0.19 & 0.20 & 5.93 & 0.00 \\
\hline
\end{tabular}

By adding military role identities in the second step, the explained variance increased significantly with $4 \%$ up to $14 \%$, suggesting that both peacekeeper role identity and warrior role identity predicted unique variance in OCB, with peacekeeper role identity $(\beta=0.29$, $t=8.66, p=0.00)$ again predicting a greater proportion of variance than warrior role identity $(\beta=0.16, t=4.62$, $p=0.00)$. 
Tab. 6: Combined and unique prediction of OCB based on military role identity

\begin{tabular}{lllll}
\hline Model summary & OCB & & & \\
\hline & $\boldsymbol{R}^{\text {adjusted }}$ & $\boldsymbol{\Delta} \boldsymbol{R}^{\mathbf{2}}$ & $\boldsymbol{F}\left(\boldsymbol{\Delta} \boldsymbol{R}^{2}\right)$ & $\boldsymbol{p}$ \\
\hline Step 1 & 0.04 & 0.05 & 9.48 & 0.00 \\
Step 2 & 0.14 & 0.10 & 46.45 & 0.00 \\
Step 1 & $\boldsymbol{B}$ & $\boldsymbol{\beta}$ & $\boldsymbol{t}$ & $\boldsymbol{p}$ \\
Constant & 3.95 & - & 31.904 & 0.00 \\
Age & 0.01 & 0.15 & 4.11 & 0.00 \\
Gender & -0.28 & -0.10 & -2.93 & 0.00 \\
Marital & 0.08 & 0.06 & 1.78 & 0.08 \\
Unit & -0.02 & -0.02 & -0.46 & 0.65 \\
Step 2 & $\boldsymbol{B}$ & $\boldsymbol{\beta}$ & $\boldsymbol{t}$ & $\boldsymbol{p}$ \\
Constant & 2.48 & - & 12.55 & 0.00 \\
Age & 0.01 & 0.14 & 3.91 & 0.00 \\
Marital & 0.09 & 0.08 & 2.29 & 0.02 \\
Gender & -0.20 & -0.07 & -2.20 & 0.03 \\
Unit & -0.06 & -0.06 & -1.60 & 0.11 \\
Peacekeeper & 0.28 & 0.29 & 8.66 & 0.00 \\
Warrior & 0.14 & 0.16 & 4.62 & 0.00 \\
\hline
\end{tabular}

\section{Summary and discussion}

In this article, we have focused on relationships between demographics (unit, gender, age and marital status), military role identities and self-esteem, organizational commitment and OCB. We performed correlation analysis and we examined the influence of these demographic variables on military role identity to find evidence for antecedents of military role identity. Over the years, studies have relied on military role identity as a unidimensional construct. However, as discussed in our theoretical review, the WPRIS was developed to measure both identities as independent identities. Our results clearly support this: the two military role identities are uncorrelated as we expected based on our previous studies and other studies (Azari et al. 2010; Broesder et al. 2015; Wong 2004). Soldiers identify with both roles at the same time, and a preference for one role is not linked to a preference for the other. Looking more closely at the psychometric qualities of the WPRIS, we found clear similarities in validity and reliability in comparison with previous studies. Thus, the WPRIS is a useful and relevant instrument to measure military role identity.

Furthermore, we have found evidence for the antecedents of military role identity. Similar to a previous Dutch study (Broesder and Op den Buijs 2015), warrior unit and age have emerged as important antecedents for the formation of warrior role identity. However, the warrior role identity likely varies with the nature of dominant tasks (being part of a combat unit or a combat-support unit). Britt (2003) demonstrated that soldiers of combat units were more likely not to be in favor of a peacekeeping operation, and soldiers whose military occupational specialty was armor, crewman or infantry were more likely to say that a peacekeeping mission was not relevant to their role as soldier. Our study also largely confirms that demographic variables predict peacekeeper role identity; age and gender are antecedents, although the predicted amount of variance is small. Women relate mainly to the peacekeeper role identity and identify more with the helping and supporting aspects of the peacekeeper identity.

With respect to the influence of military role identity on self-esteem, organizational commitment and OCB, our research confirms that military role identities are not only independent but also very important in their relationship with these outcome variables. While peacekeeper role identity predicts all outcome variables, the warrior role identity only predicts organizational commitment and OCB and is not related to self-esteem at all. A possible explanation can be the institutional forces upon which soldiers build their perceptions of warrior role identity instead of self-esteem. Military socialization and other institutional practices, norms, values and cultures shape how soldiers perceive their military role, and these factors are not only relevant in individual identity formation but also in behavior. Although there have been many transformations concerning the warrior identity definition due to political, social and cultural changes, the warrior ethos is still recognized as playing a crucial role in military socialization processes, where soldiers will be hardened and prepared for battle and trying to meet operational requirements (Dalenberg 2017; Talbot 2012). Socialization processes and contemporary training shape a sense of expertise, power, bravery, vigor and courage (Kaurin 2014; Talbot 2012) and are likely to lead to loyal and responsible behavior (Dalenberg 2017). Therefore, we believe that warrior role identity may be related to self-confidence or physical and moral courage, concepts we did not measure. Instead, we measured personal self-esteem based on the Self-Esteem-Scale of Rosenberg (1965) which refers to feelings of selfacceptance, self-competence, self-worth and the sense of own values within a certain situation (Wahyu Ariani 2012). These feelings appeared to be predicted by peacekeeper role identity, most likely because peacekeepers are able to make sense of the situation, and they perceive the situation as relevant to their identity (Britt 2003). This finding and the knowledge from previous studies confirm that self-esteem is an important aspect in the 
military context. Self-esteem not only helps soldiers in being flexible, it may also prevent stress in demanding, ambiguous and dangerous situations, and it could influence feelings of competence and enhance persisting task performance (Van Boxmeer et al. 2008). It should be clear that more attention should be paid to the creation of peacekeeper role identity in military training, preparation and socialization activities. Nevertheless, further research is required for understanding the relationship between peacekeeper role identity and self-esteem.

With respect to organizational commitment and OCB, peacekeeper role identity also appeared to be a highly important predictor variable next to warrior role identity. Given that organizational commitment and OCB are key constructs in the workplace and in organizational research leading to organizational effectiveness and individual performance, our findings are important for the military. Although we did not apply the most commonly used affective component of Meyer's et al. (1993), we found positive relationships between military role identity and organizational commitment. Our previous findings were confirmed; military role identity, and in particular peacekeeper role identity, predicts a substantial amount of variance in organizational commitment.

Moreover, organizational commitment in turn is related to OCB. Also, OCB is a unique aspect, and similar to organizational commitment, it is important for organizational effectiveness and individual performance. According to Organ (1994), it refers to the "good soldier" prototype in the military context. Although we measured OCB with a relative limited subset of items of OCB, referring only to the helping dimension of the OCB construct, we found positive relationships between military role identity and OCB, whereas peacekeeper role identity appeared to be a stronger predictor than warrior role identity. Other studies demonstrated that there are more interesting dimensions of OCB in a military context (Goffin et al. 2013; Van Creij 2017). Actually, Goffin et al. (2013) suggested that a nine-dimensional approach would be more appropriate in a military context. This could be a focus in further research concerning military role identity and OCB. Moreover, studies suggest that leadership may also play an important role in the development of OCB in the military (Dalenberg 2017; Goffin et al. 2013; Van Creij 2017). Examining the role of leadership in the relationship between military role identity and OCB is another step to be taken in further research. In summary, military role identity is important in predicting self-esteem, organizational commitment and OCB, whereas peacekeeper role identity is the strongest predictor for these work-related aspects.

\subsection{Limitations and future research directions}

In this study, we faced a few methodological issues. First, regarding the sample and with all participants as army personnel, only one military service was represented. Research with larger and more controlled populations from different nations and other military services will allow a generalization of the results. In addition, we collected data from four countries which were very similar to some extent of the military culture, socialization and training of military personnel. Our study would have been more complete if more countries (and dissimilar countries) would have been surveyed. However, this sampling method would require a more complex approach in order to monitor the effects of more diverse cultural backgrounds.

In addition, in this study, we used convenience sampling, which made it difficult to determine how many questionnaires were actually sent out in the countries and how many people refused to complete the questionnaire.

Furthermore, the results may partly be influenced by common method variance because of the self-reported questionnaire that measured military role identities and the outcome variables at one point in time (Jakobsen and Rasmus 2015). More extensive research with different samples and data collection methods would provide broader evidence for the results.

For further research, it would also make military role identity studies more complete if actual behavior would also be measured next to military role identity, selfesteem, organizational commitment and OCB. The behavior intentions we measured are closely related to actual behavior during missions; however, we did not measure actual behavior or performance of military personnel.

Another issue concerns the translation of the questionnaire. Although the results show uniformity and no consistent differences were found with regard to the principal understanding and internal consistency after careful processed translation into different languages, we did not use the "back translation" technique as method for ensuring a clear, unambiguous and understandable translation of specific items in the questionnaire. This may have caused some bias due to misinterpretations or different interpretation of the items in the questionnaire. It is advisable to make use of this procedure (Brislin 1970).

\section{Conclusion}

Soldiers perform in dangerous and unpredictable situations; hence, insight into their military role identity is 
of utmost importance to predict their behavior. Future researchers and commanders may therefore benefit from the use of the WPRIS for international survey studies as well as for practical use. Furthermore, this research supports the presumption that dimensions of peacekeeper role identity, such as reconstruction, support and diplomacy, are even more important contributors to selfesteem, organizational commitment and OCB than the way soldiers perceive force and military power, tasks embedded in warrior role identity. As peacekeeper role identity influences important and desirable intentions and behavior, focusing on this identity in socialization and training for operations may not only influence soldiers' behavior but also benefit organizational effectiveness and performance. Moreover, the implications of the relationship between military role identity and workrelated aspects suggest that military leaders should be aware - in advance - of the perceptions of the military role and expectations within their military units and the effects on behavior. Although future studies should be conducted to further explore and evaluate the potential impact of military role identity through work-related aspects on soldiers' behavior and organizational performance, the findings provide a clear and fruitful insight into the relationships between military role identity and self-esteem, organizational commitment and OCB.

\section{References}

Allen, N. J. (2003). Organizational commitment in the military. Military Psychology, 15(3), pp. 237-253.

Allen, N. J., \& Meyer, J. P. (1990). The measurement and antecedents of affective, continuance and normative commitment to the organization. Journal of Occupational Psychology, 63, pp. 1-18.

Avant, D., \& Lebovic, J. (2000). US military attitudes toward post-Cold War missions. Armed Forces \& Society, 27, pp. 37-56.

Azari, J., Dandeker, C., \& Greenberg, N. (2010). Cultural stress: How interactions with and among foreign populations affect military personnel. Armed Forces \& Society, 36(4), pp. 585-603.

Bartel, C. A. (2001). Social comparisons in boundary-spanning work: Effects of community outreach on members' organizational identity and identification. Administrative Science Quarterly, 46, pp. 379-413.

Bartone, P., \& Vaitkus, M. A. (1998). Dimensions of psychological stress in peacekeeping. Military Medicine, 163(9), pp. 587-593.

Baumeister, R. F., Campbell, J. D., Krueger, J. I., \& Vohs, K. D. (2003). Does high self-esteem cause better performance, interpersonal success, happiness, or healthier lifestyles? Psychological Science in the Public Interest, 4, pp. 1-44.

Bentein, K., Vandenberg, R., Vandenberghe, C., \& Stinglhamber, F. (2005). The role of change in the relationship between commitment and turnover: A latent growth modeling approach. Journal of Applied Psychology, 90, pp. 468-482.
Brewin, C. R., Garnett, R., \& Andrews, B. (2011). Trauma, identity and mental health in UK military veterans. Psychological Medicine, 41, pp. 1733-1740.

Brislin, R. W. (1970). Back-translation for cross-cultural research. Journal of Cross-Cultural Psychology, 1(3), pp. 185-216.

Britt, T. W. (1998). Psychological ambiguities in peacekeeping. In Langholtz, H. J. (ed.), The Psychology of Peacekeeping. Praeger Publishers/Greenwood Publishing Group, Westport, CT, US, pp. 111-128.

Britt, T. (2003). Can participation in peacekeeping missions be beneficial? The importance of meaning as a function of attitudes and identity. In: Britt, T. W., \& Adler, A. B. (eds.), The Psychology of the Peacekeeper. Lessons from the Field. Praeger, Westport, CT, London, pp. 7-88.

Broesder, W. A. (2011). Soldiers wielding swords and ploughshares; the significance of military role identity. Doctoral dissertation. University of Leuven, Belgium.

Broesder, W. A., \& Op den Buijs, T. P. (2015). Militaire rolidentiteit, een onderzoek naar militaire rolidentiteit van Nederlandse eenheden in de kazernesituatie. Research Paper, No.106. the Netherlands Defence Academy, Breda.

Broesder, W. A., Op den Buijs, T. P., Vogelaar, A. L. W., \& Euwema, M. C. (2015). Can soldiers combine swords and ploughshares? The construction of the Warrior - Peacekeeper Role Identity Survey (WPRIS). Armed Forces \& Society, 41, pp. 519-540.

Bryman, A. (2016). Social Research Methods, 5th edn. Oxford University Press, London.

Dalenberg, S. (2017). Officer, practise what you preach! Research on effects and interventions in military officer socialisation at the Royal Military Academy Dissertation, Radboud University, Nijmegen.

Errol, R. Y., \& Orth, U. (2011). Self-esteem development from age 14 to 30 years: A longitudinal study. Journal of Personality and Social Psychology, 101(3), pp. 607-19.

Franke, V. C. (1999a). Resolving identity tensions: The case of the peacekeeper. Vol. XIX, 2. Available at https://journals.lib.unb. $\mathrm{ca} /$ index.php/jcs/article/view/4359/5017.

Franke, V. C. (1999b). Preparing for Peace: Military Identity, Value Orientations, and Professional Military Education. Greenwood Publishing Group, Westport, CT, USA.

Franke, V. C. (2000). Duty, honor, country: The social identity of West Point cadets. Armed Forces \& Society, 26, pp. 175-202.

Franke, V. C., \& Guttieri, K. (2009). Picking up the pieces: Are United States officers ready for nation building? Journal of Political and Military Sociology, 37, pp. 1-25.

Fu, F. Q., Bolander, W., \& Jones, E. (2009). Managing the drivers of organizational commitment and salesperson effort: An application of Meyer and Allen's three-component model. Journal of Marketing Theory and Practice, 17, pp. 335-350.

Gade, P. A. (2003). Organizational commitment in the military: An overview. Military Psychology, 15, pp. 163-169.

Goffin, D., Woychesin, D., Hoffman, B., \& George, K. (2013). The dimensionality of contextual and citizenship performance in military recruits: Support for nine dimensions using self-, peer, and supervisor ratings. Military Psychology, 5(25), pp. 478-488.

Goffman, E. (1975). Totale Instituties. Universitaire Pers, Rotterdam.

Griffeth, R. W., Hom, P. W., \& Gaertner, S. (2000). A meta-analysis of antecedents and correlates of employee turnover: Update, 
moderator tests, and research implications for the next millennium. Journal of Management, 26, pp. 463-488.

Griffith, J. (2009). Being a reserve soldier: A matter of social identity. Armed Forces and Society, 36(1), pp. 38-64.

Griffith, J. (2010). Decades of transition for the U.S. reserves: Changing demand on reserve identity and mental well-being. International Review of Psychiatry, 23, pp. 181-191.

Griffith, J. (2011). Contradictory and complementary identities of U.S. Army Reservists: A historical perspective. Armed Forces and Society, 37(2), 261-283.

Gurbuz, S. (2009). Some possible antecedents of military personnel organizational citizenship behavior. Military Psychology, 21(2), pp. 200-215.

Haslam, S. A., Jetten, J., Postmes, T., \& Haslam, C. (2009). Social identity, health and wellbeing: An emerging agenda for applied psychology. Applied Psychology, 58(1), 1-23.

Hogg, M. A., Terry, D. J., \& White, K. M. (1995). A tale of two theories: A critical comparison of identity theory with social identity theory. Social Psychology Quarterly, 58, pp. 255-269.

Homan, K. (2007). De militair en Wederopbouw: Zo civiel als mogelijk en zo militair als nodig. Internationale Spectator, 61, pp. 63-67.

Jakobsen, M., \& Rasmus, J. (2015) Common method bias in public management studies. International Public Management Journal, 18(1), 3-30.

Jaros, S. (2007). Meyer and Allen model of organizational commitment: Measurement issues. Journal of Organizational Behavior, 6, pp. 7-25.

Jaros, S. T., Jernier, J. M., Koehler, J. W., \& Sincich, T. (1993). Effects of continuance, affective and moral commitment on the withdrawal process: An evaluation of 8 structural equation models. Academy of Management Journal, 36, pp. 951-995.

Johanson, R. B., Laberg, J. C., \& Martinussen, M. (2013). Measuring military identity: Scale development and psychometric evaluations. Social Behavior and Personality, 41(5), pp. 861-880.

Judge, T. A., Locke, E. A., Durham, C. C., \& Kluger, A. N. (1998). Dispositional effects on job and life satisfaction: The role of core evaluations. Journal of Applied Psychology, 83, 17-34.

Katz, D., \& Kahn, R. L. (1966). The Social Psychology of Organizations. Wiley, New York.

Kaurin, P. M. (2014). The Warrior, Military Ethics and Contemporary Warfare: Achilles Goes Asymmetrical. Ashgate Publishing, London.

Lancaster, S. L., \& Hart, R. P. (2015). Military identity and psychological functioning: A pilot study. Military Behavioral Health, 3, pp. 83-87.

Langkamer, K. L., \& Ervin, K. S. (2008). Psychological climate, organizational commitment and morale: Implications for army captains' career intent. Military Psychology, 20, pp. 219-236.

Lazarus, R. S., \& Folkman, S. (1984). Stress Appraisal and Coping. Springer Publishing Company, New York.

Luchak, A. A., \& Gellatly, I. R. (2007). A comparison of linear and nonlinear relations between organizational commitment and work outcomes. Journal of Applied Psychology, 92, pp. 786-793.

Mathieu, J. E., \& Zajac, D. M. (1990). A review and meta-analysis of the antecedents, correlates, and consequences of organizational commitment. Psychological Bulletin, 108, pp. 171-194.
Meyer, J. P., \& Allen, N. J. (1991). A three-component conceptualization of organizational commitment. Human Resource Management Review, 1, pp. 61-89.

Meyer, J. P., Allen, N. J., \& Smith, C. A. (1993). Commitment to organizations and occupations: Extension and test of a three-component conceptualization. Journal of Applied Psychology, 78, pp. 538-551.

Meyer, J. P., Kam, C., Goldenberg, I., \& Bremner, N. L. (2013). Organizational commitment in the Military: application of a profile approach. Military Psychology, 25, pp. 381-401.

Meyer, J. P., Stanley, D. J., Herscovitch, L., \& Topolnystsky, L. (2002). Affective, continuance and normative commitment to the organization: A meta-analysis of antecedents, correlates, and consequences. Journal of Vocational, 61, pp. 20-52.

Motowidlo, S. J., Borman, W. C., \& Schmit, M. J. (1997). A theory of individual differences in task and contextual performance. Human Performance, 10(2), pp. 71-83.

Op den Buijs, T. P., \& Broesder, W. A. (2013). Effective behavior in meaningful missions. In: Van Amersfoort, H., Moelker, R., Soeters, J., \& Verweij, D. (eds.), Moral Responsibility \& Military Effectiveness. Asser Press, The Hague, pp. 157-171.

Op den Buijs, T. P., Broesder, W. A., \& Meijer, M. (2012). Strain and stress; role ambiguity in an unfriendly environment. In: Beeres, R., Van der Meulen, J., Soeters, J., \& Vogelaar, A. (eds.), Mission Uruzgan, Collaborating in Multiple Coalitions for Afghanistan. Amsterdam University Press, Pallas Publications, Amsterdam, pp. 107-119.

Organ, D. W. (1988). Organizational Citizenship Behavior: The Good Soldier Syndrome. Lexington Books, Lexington, MA.

Organ, D. W. (1994). Organizational citizenship behavior and the good soldier. In: Rumsey, M. G., Wallace, C. B., \& Harris, J. H. (eds.), Personnel Selection and Classification. Erlbaum, Hillsdale, NJ, pp. 53-6.

Organ, D. W., Podsakoff, P. M., \& MacKenzie, S. B. (2006). Organizational Citizenship Behavior: Its Nature, Antecedents and Consequences. Sage Publications, London.

Petlichkoff, L. M. (2004). Self-regulation skills for children and adolescents. In: Weiss, M. R. (ed.), Developmental Sport and Exercise Psychology. Fitness Information Technology, Morgantown, WV, pp. 272-292.

Reed, B. J., \& Segal, D. R. (2010). The impact of multiple deployments on soldiers' peacekeeping attitudes, morale, and retention. Armed Forces \& Society, 27, pp. 57-78.

Rosenberg, M. (1965). Society and the Adolescent Self-Image. Princeton University Press, Princeton, NJ.

Schacter, D. L., Gilbert, D. T., \& Wegner, D. M. (2009). Self Esteem. Psychology, 2nd edn. Worth, New York.

Smith, R. T., \& True, G. (2014). Warring identities: Identity conflict and the mental distress of American veterans of the wars in Iraq and Afghanistan. Society and Mental Health, 4(2), pp. 147-161.

Sobel, M. E. (1986). Some new results on indirect effects and their standard errors in covariance structure. Sociological Methodology, 16, 159-186.

Talbot, S. (2012). Warriors, Warfighting and the Construction of Masculine Identities. Available at https://tasa.org.au/ wp-content/uploads/2012/11/Talbot-Steven.pdf.

Task Group HFM-163. (2012). Improving the Organisational Effectiveness of Coalition Operations (Amélioration de l'efficacité structurelle des opérations en coalition). RTO Technical Report, NATO, AC/323(HFM-163)TP/476. 
Thoits, P. A. (1991). On merging identity theory and stress research. Social Psychology Quarterly, 54, pp. 101-112.

Turner, J. C., \& Tajfel, H. (1986). The social identity theory of intergroup behavior. Psychology of Intergroup Relations, 5, pp. 7-24.

Van Boxmeer, L. E. L. M., Duel, J., de Bruin, R., \& Verwijs, C. (2008). Het operationele belang van moreel. Hoe werkt het en hoe meten we het? Militaire Spectator, 177(7/8), 415-426.

Van Boxmeer, L. E. L. M., Verwijs, C., Euwema, M., \& Van Dalenberg, S. (2010). Assessing Morale and Psychological Distress during Modern Military Operations. Rapport GW-10-138. The Netherlands' Defense Services Centre Behavioral Sciences, The Hague.

Van Creij, I. (2017). “The good soldier syndrome”; Een onderzoek naar het stimuleren van OCB gedrag van ondergeschikten door leidinggevenden. Bachelorscriptie NLDA, Breda.
Wahyu Ariani, D. (2012). Linking the self-esteem to organizational citizenship behavior. Business and Management Review, 1(2), pp. 27-38.

White, K. M., Thomas, I., Johnston, K. L., \& Hyde, M. K. (2008). Predicting attendance at peer-assisted study sessions for statistics: Role identity and the theory of planned behavior. Journal of Social Psychology, 148(4), pp. 473-492.

Wiley, M. G. (1991). Gender, work, and stress: The potential impact of role-identity salience and commitment. Sociological Quarterly, 32, pp. 495-510.

Williams, L. J., \& Anderson, S. E. (1991). Job satisfaction and organizational commitment as predictors of organizational citizenship and in-role behaviors. Journal of Management, 17(3), pp. 601-617.

Wong, L. (2004). Developing Adaptive Leaders: The Crucible Experience of Operation Iraqi Freedom. Strategic Studies Institute, US Army War College, Carlisle, PA. 